\title{
Assessing the Potential of Real Estate Investment Trust in Financing Real Estate Development Projects
}

\author{
Philips Nnajiofor Egbo ${ }^{1}$, Obinna Collins Nnamani ${ }^{2 *}$ Amaka Amanda Amuta $^{3}$ \\ 1. Department of Estate Management, Faculty of Environmental Sciences, Enugu State University of Science \\ and Technology, Agbani, Enugu State, Nigeria \\ 2. Department of Estate Management, Faculty of Environmental Studies, University of Nigeria, Enugu Campus, \\ Enugu 400001, Enugu State, Nigeria \\ 3. Nigeria Immigration Service, Abuja FCT, Nigeria
}

\begin{abstract}
One of the crucial challenges facing real estate development in Nigeria is finance. The informal sources of finance are grossly inadequate, and access to formal finance instruments is difficult. This study aimed at investigating the potential of REIT structure as an option for financing real estate development in Nigeria. The specific objectives of the study were to; evaluate the external factors influencing the performance, future growth and development of N-REITs as it affects funding of real estate development projects; and appraise the future prospects of N-REITs as a viable option in financing real estate development projects. A survey research design was adopted for the study. A sample of 275 stakeholders comprising 221 real estate developers, and 54 senior staff members of Securities and Exchange Commission (SEC), all in Abuja, were conveniently selected for the study. Frequency, percentage, mean, and standard deviation were used to analyse the data. Findings show that equity capital (47.8\%), commercial banks (26.2\%), and mortgage banks (16.5\%) are the major sources of real estate development finance in Nigeria. The key external factors influencing $N$-REITs performance were strategic property locations $(4.43 \pm 0.82)$, tax treatment $(4.34 \pm 0.78)$, and political risks $(4.10 \pm 1.12)$; while the most important prospects of $N$-REITs in financing real estate development projects include; increase in supply of real properties $(4.1 \pm 1.02)$, portfolio diversification $(3.88 \pm 1.10)$, and liquidity in real estate sector $(3.69 \pm 1.22)$. The study concludes that, in implementing high level sensitisation, transparency, infrastructure provision and review of regulations guiding REIT's operation, N-REIT most probably becomes a viable option for financing real estate development.
\end{abstract}

KEYWORDS: Real estate investment trust, real estate development, development finance, Abuja

\section{INTRODUCTION}

One of the crucial challenges facing real estate development in Nigeria is finance. Given that real estate development is capital intensive, it is inevitable that developers will need external support to finance their development projects. The informal sources of finance are grossly inadequate for any meaningful real estate development due to the required huge capital outlay and the complex economic situation. Although there are multiple formal finance instruments currently available, access to such funds still remains difficult and restricted as a result of minimum stipulation of monetary policies on the amount insurance companies and pension funds could invest in real estate development. Also, the high interest rate commercial banks charge on real estate and construction loans constrains the developers and investors, making mortgage loan unattractive to them. The long list of developers on the waiting list for Federal Mortgage Bank loans and other Federal Government loan is discouraging. The failure of conventional sources to provide the required finance to expand real estate developments create the need for alternative sources of finance such as securitisation, unitisation and real estate development trust.

Real estate development projects require huge financial outlay which cannot be provided alone by the developer/investor but requiring credit financing from various sources. Finance for real estate is grouped into two major sources - the conventional and the contemporary sources. The conventional/traditional sources are sub-divided into formal and informal. The informal source is equity contribution from personal savings of the 
DOI: $\underline{10.51386 / 25815946 / \mathrm{ijsms}-\mathrm{v} 4 \mathrm{i} 5 \mathrm{p} 118}$

Volume: 4 Issue: 5

September to October 2021

https://www.ijsmsjournal.org

developer. Other informal sources include esusu/ajo, village development scheme, social club, age grade association, cooperative society and town unions. The formal sources are usually funds borrowed from banks, pension funds, insurance companies and primary mortgage institutions (Ajibola, Oleyede, and Oni 2009). The conventional sources may be good in the traditional settings, but the complex economic situation and the large consideration for development have made these sources grossly inadequate for substantial real estate development in Nigeria. Bruegerman and Fisher (2002) state that debt financing is very common but constrained by the long-term nature of real estate development as against short-term nature of the lenders' sources of fund. Debt financing is also available through non-bank institutions such as pension funds, finance houses and insurance companies, but these are limited by regulations that determine the proportion of total funds that could be invested in real estate development.

Real estate development is a crucial enterprise in the advancement of any nation. Advanced nations in the world such as the United States of America (USA), United Kingdom (UK), Australia, etc. have a considerable large stock of real estate investments which have contributed immensely to the socio-economic development of these nations. For instance, real estate mortgage sector contribute 56\% to the GDP of the US, $40 \%$ for the UK and $45 \%$ in Australia. This is not the case with most developing nations such as Nigeria. Near current statistics indicated that real estate sector's contribution to gross domestic product (GDP) in Nigeria has fluctuated in the region of $7 \%$ between 2010 - 2012. In 2010, it was 7.56\%, it went down to $7.28 \%$ in 2011 and increased slightly to $7.73 \%$ in 2012 (NBS, 2015). This dismal performance of the real estate sector in the nation's economy could be attributed to the low stock of real estate in Nigeria. This development could be attributed to some challenges confronting real estate development which chief amongst them is access to development finance.

Evaluating the factors influencing REIT performance could help in decision-making process that will improve the growth, performance and development of N-REIT. Earlier studies have identified various factors affecting the performance and growth of REIT (Olanrele et al., 2015a). These factors are classified into formal and informal factors (Baum \& Murray, 2010; Baum, 2008). The informal or external factors are regarded as socio-political factors or operating environment factors which include political risk, investor's behavior/sentiments, infrastructure, social security and regulations; while the formal or internal factors are regarded as economic and market factors, and include size, FFO, NAV, leverage, share price and asset value and diversification. For N-REIT, Olanrele et al. (2014) investigated the influence of external factors on N-REIT return without evaluating the multivariate effect of these factors in the study. These factors have adversely impacted the performance of N-REIT. At its present state, the N-REIT is not viable as an alternative funding vehicle for property development in Nigeria.

Few studies have investigated the challenges and prospects of N-REITs (Odunsi, 2011; Keke and Emoh, 2015; Ajibola et al., 2009; and Olanrele, 2016). This paper aims at assessing the external factors that impact NREIT as an alternative source of finance for real estate development projects and prospects of N-REIT as a viable option for real estate development in Nigeria. Establishing and assessing these factors will enhance the capacity of N-REIT to finance real estate development projects in Nigeria considering the prospects. This paper contributes to the body of knowledge on the potential prospects of REIT structure as a viable option for real estate development projects especially in developing countries such as Nigeria with limited stock of real estate. The remainder of this paper is divided into five sections. Section two, literature review, synthesised studies that investigated the external factors influencing REIT performance and prospects of the REIT structure as it relates to real estate generally. Section three, the methodology, encapsulates the study design which outlines the steps adopted in gathering and analysis of data. In section four, the results of the data analysed were presented in tables. The results and their implications were discussed in section five; while in the final section, i.e. the conclusion, recommendations; policy implications and future studies were proffered

\section{LITERATURE REVIEW}

Literature has identified factors that influence REITs performance and growth and have been categorised into two major groups. They are the formal factors (economic and market) which are net asset value (NAV), funds from operations (FFO), size of the asset, leverage, share price, asset value and diversification. The 
DOI: $\underline{10.51386 / 25815946 / \mathrm{ijsms}-\mathrm{v} 4 \mathrm{i} 5 \mathrm{p} 118}$

Volume: 4 Issue: 5

September to October 2021

https://www.ijsmsjournal.org

informal factors (i.e. the operating environment) include political risks, investors' behaviour, infrastructure, opaqueness, and hostile business environment, etc. This paper focuses on the informal/external factors.

Olanrele (2016), in one of the objectives of his study, investigated both the internal and external factors influencing the growth and development of N-REITs. For factors affecting REIT performance, findings show that the external factors affect REIT performance. Respondents agreed that all the external factors affect the performance of N-REIT. The results are as follows: Investors sentiments (212, 93.4\%), Security (147, 64.8\%), Political leadership/risk (218, 96\%), Infrastructure (177, 78\%), Internal management (202, 89\%). The five (5) most influential factors were scored in order of preference. Capitalization (4.08) was ranked first, followed by infrastructure (3.12), external management (3.04), asset value (2.71) and income (1.61).

The three (3) Nigerian REITs; SKYESHELT, UHOMREIT and UPDCREIT were established in 2007, 2008, and 2013 respectively. The first N-REIT, SKYESHELT was introduced 13 years ago, making it one of the oldest in Africa. Unfortunately, the three (3) NI-REITs have performed below expectation in their market value and financial performance. The total market value of the REITs is not up to 50 billion naira which is less than $0.4 \%$ of market capitalization of the NSE unlike in the New York Stock Exchange (NYSE) where REITs account for between $2.5 \%$ to $5 \%$ of the total market capitalization (Odubola, 2019). The stock market values instead of increasing based on the initial opening price is either stagnant or decreasing with unattractive earnings. Having only 3 REITs since the enactment of Investment and Security Act in 2007 is a clear evidence that the NREITs have not performed well unlike South Africa with about 50 REITs. The reason most investors shy away from them according to Odubola (2019). Notwithstanding the poor performance, growth and development of the N-REITs, there are prospects for growth, high performance, and the capacity for N-REITs to fund real estate development projects in Nigeria.

There are various advantages of using REITs as a means of financing real estate projects that can be seen from other countries in which the REITs have been successfully implemented. Quite a number of literature have investigated the benefits/advantages of REITs globally, in which some have articulated as prospects. Some of these literatures have investigated these prospects either collectively or separately. For instance extant literature by Kamua (2016) and Alao (2018) established some prospects of REIT. These include; increased property supply, new pool of real estate investors, huge source of capital for various real estate projects, access to low cost of fund, liquidity, diversification of real estate portfolio, tax benefits, hedge against inflation, equitable ownership of various real estate, superior dividends and earnings, and economic growth.

The study by Kamua (2016) investigated the challenges and prospects of real estate investment trusts (REITs) in funding real estate development in Kenya. One of the objectives of the study was to identify the prospects of REIT and establish the extent to which the prospects affect the financing of real estate in Kenya. An exploratory study design approach was adopted for the study. The population of the study comprises 156 different development companies in Nairobi County. A sample size of 70 development companies was selected for the study. Primary data were collected using questionnaire. The number of questionnaire returned was 50 out of 70 given a response rate of $71 \%$. Results from data analysis show that $64 \%$ of the development firms (respondents) agree that increased residential and commercial properties as a result to increased supply of real properties is a prospect of REITs. Other prospects are; pool of new investors in real estate which would create greater availability of resources, 50\%; equitable ownership of the various real estate properties in Kenya, $40 \%$; huge source of capital for various real estate projects, $82 \%$; high liquidity in the real estate sector, $52 \%$; and access to low cost of funds for development projects, 44\%. Alao (2018) highlighted some prospects of REITs in Nigeria which are; hedge against inflation, tax benefit, economic growth, high and reliable returns, and liquidity and diversification of investment portfolio. Some potential prospects of REITs are discussed hereunder:

\section{Hedge against inflation}

Empirical studies have shown that evidence to the question whether REIT is an effective hedge against inflation or not is indefinite. Christon, Gupta, Nyakabawo, and Wohar (2018), assert that empirical evidence supporting REITs as good inflation hedge is ambiguous since some evidence support REITs as a good inflation hedge, while others show that REITs are not good inflation hedge. Empirical studies by Chang (2017) and Pierdzioch, Risse, Gupta, and Nyakabawo (2019) show mixed results on whether REIT provides a good hedge 
DOI: $\underline{10.51386 / 25815946 / \mathrm{ijsms}-\mathrm{v} 4 \mathrm{i} 5 \mathrm{p} 118}$

Volume: 4 Issue: 5

September to October 2021

https://www.ijsmsjournal.org

against inflation. Chang (2017) explores the inflation-hedging ability of REIT index using the Markovswitching GRG copula. Findings show that the dependence between REIT return and inflation rate is mixed. The REIT index is not a hedge against inflation risk during the period of negative dependence; while the REIT has a partially inflation hedging ability during the period of positive dependence. Erol and Tirtiroglu (2008) empirically investigated the inflation-hedging capacity of Turkish REITs as against the indices of common stocks listed on Instabul Stock Exchange (ISE) over a period comprising high and moderate inflation rates. Results show that Turkish REIT generally provides a better hedge against both actual and expected inflation than the ISE common stock indices.

The hedging capacity of REITs is better under high inflation than under moderate inflation. REITs in Nigeria could provide a better inflation-hedging capacity since the real estate income tends to increase in the same proportion with the inflation rate. Nevertheless, it should be noted that during severe economic downturn, REITs might not provide a better hedge against inflation.

\section{Superior dividend and earnings}

The indices used for measuring the performance of REIT include dividend yield, net asset value (NAV), and the growth in the stock market price. Over time empirical evidences have shown that REITs post a high dividend yield compared to other commensurate stocks; also they post superior return compared to other equivalent stocks. According to Block (2011), REITs dividend yields tend to be to some extent correlated with and generally higher than yields on 10-year U.S. Treasury bonds. However, unlike the majority high yielding investments, REITs shares have strong possibility of increasing in value time given that REITs' properties value increase and additional properties are acquired and added to the portfolio. Extant literature has also demonstrated the superior performance capacity of different global REITs over stocks (Newell and Marzuki, 2018; Ntuli and Akinsomi, 2017; Newell and Marzuki, 2016; Newell, Pham, and Ooi, 2015; and Rozman, Azmi, Mohd, and Razali, 2015).

Studies conducted in Asia (Newell, Pham, and Ooi, 2015; and Rozman, Azmi, Mohd, and Razali, 2015) empirically proved that REITs outperformed stocks. Newell, Pham, and Ooi, (2015) investigated the riskadjusted performance, significance and portfolio diversification benefits of Singapore REITs (S-REITs) in a mixed-asset portfolio context in Singapore over 2003 - 2013. Findings show that S-REITs outperformed stocks by delivering strong risk-adjusted returns, being the best performed asset class. In Malaysia, Islamic REITs (IREITs) outperformed both shares and bonds (Rozman, Azmi, Mohd, and Razali, 2015). Empirical evidences from Europe (Newell and Marzuki, 2018; Newell and Marzuki, 2016), presented mixed results. For instance Newell and Markuzi (2016) appraised the risk-adjusted performance, significance and portfolio diversification benefits of UK-REITs in a mixed-asset portfolio from 2007 to 2014 using monthly total return. Sub-period analysis over July 2009 - December 2014, post Global Financial Crisis (GCF) recovery of UK-REITs was also conducted. Empirical results show that on risk-adjusted basis, the UK stock (4.49\% p.a.) performed better than the UK-REITs (-2.23\% p.a.). However, for the post-GCF recovery period, UK-REITs (18.98\% p.a.) delivered a superior performance than the UK stocks (12.08\% p.a.).

In Africa, Ntuli and Akinsomi (2017) assessed the risk-adjusted performance of South Africa REITs over May 2013 - December 2015. Results show that South Africa REITs outperformed shares, bonds, T-bills and other listed property in a mixed-asset portfolio. Furthermore, the REITs performed better than UK, European, and Asian REITs. Consequently, it could be reasoned that if Nigeria REITs are deployed in real estate development, N-REITs performance will be enhanced since South Africa has a large stock of real estate than Nigeria, besides there was a period that the Nigerian GDP superseded that of South Africa which implies that the N-REITs has greater prospects of replicating South Africa REITs performance.

\section{Tax benefit/advantage}

An important distinguishing features of REITs in comparison with other companies is that most global REITs such as the United States REITs, Australia REITs, Canada REITs, and the United Kingdom REITs' income distributed as dividends are exempt from corporation tax that are supposed to be passed to investors in the REITs (shareholders). Nevertheless, incomes that are not distributed will attract corporate taxation (Abdulai, 
DOI: $\underline{10.51386 / 25815946 / \mathrm{ijsms}-\mathrm{v} 4 \mathrm{i} 5 \mathrm{p} 118}$

Volume: 4 Issue: 5

September to October 2021

https://www.ijsmsjournal.org

2013; Ozkan, 2018). In the Nigerian situation, there is a slight ambiguity on the tax system for REITs, notwithstanding; there is a huge prospect for tax free benefits, provided that they comply with certain investment and income distribution rules. Quite a number of empirical studies have investigated the impact of tax reform on REITs performance. Xu and Yiu (2017) posit that plethora of studies have investigated the impact tax reforms on REITs performance; though there is no consensus in their findings. Empirical study by Xu and Yiu (2017) shows that tax reform has positive effects on the development of REITs and REITs investors' wealth growth.

\section{Increased liquidity and divisibility}

One key characteristics of real estate asset class is low liquidity (or illiquidity). McNamara (1998) defined liquidity as 'the ability of an investor to trade assets into a cash form and vice versa. It is used more loosely to describe the speed and/or volume of transacting in a given market'. Real estate represent a huge single investment in terms of finance and cannot be sold quickly in a given market trend, unlike shares and stocks or equities. It can take months to sell a property most especially if the market conditions are not favourable. Furthermore, selling a property asset normally involves high transaction costs, such as agency fees, legal fees and government charges. Real estate is usually not sold quickly since its sale involves large sums of money and the appropriate financing may not always be readily secured. Another feature of real estate asset class that connects to illiquidity is indivisibility or lumpiness. Most properties cannot be divided into smaller units and sold separately. These features make it somewhat impossible for small fund investors to participate in real estate development projects (Reed and Sims, 2015).

One vital prospects of REIT is that it provides liquidity and divisibility for the real estate asset which is considered illiquid in the form of equity or debt securities. REITs create equity or debt securities in real estate that enables small investors to invest in real estate with minimal capital requirements by purchasing the shares created in real estate, thereby overcoming the problems of huge initial capital requirements and indivisibility (Abdulai, 2013). Quite a number of studies have investigated REIT's liquidity since 1990s. Studies by Cannon and Cole (2011), Clayton and Mackinnon (2000), have demonstrated REITs liquidity have increased over the years. Nevertheless, Cannon and Cole (2011) pointed out a period of decrease. They found out that liquidity of REIT increased during the early and mid 1990s, declined during the late 1990s and then increased significantly from 2000 to 20006, and declined in 2007. Study by Blau, Nguyen, and Whitby (2015) examined the distribution of market liquidity for REITs using multivariate tests. Findings from the study show that average bid-ask spreads are higher for REITs than for non-REITs which are consistent with literature. These studies are evidences that increased liquidity in real estate investment is a prospect of REITs financing of real estate development (Kamua, 2016).

\section{Source of development finance to increase property supply}

There is low real estate assets stock in Nigeria which is one of the impediments to REITs' regime development and growth in Nigeria. The existing REIT legislation in Nigeria favours direct acquisition of developed property. Consequently, the low stock of property has hampered the direct investment in real properties by the Nigeria REITs. This state of affair is buttressed by the fact there is housing and other forms of real estate supply deficit in Nigeria. For example, the housing deficit in Nigeria has been put at about 17 million units. In Abuja, Lagos, Ibadan, and Kano, housing need is increasing at about 20\% per year; whereas the present total output in the formal sector is not more than 100,000 units each year. It is projected that by year 2050 that three quarter of the Nigerian population would be living in cities which translates into at least 700,000 units of annual housing requirement to keep up with the urban migration and growing population over the coming decades (World Bank, 2016). Supply of real estate via development can mitigate the housing deficit; and also increase supply of other forms of real properties.

Deploying N-REITs in property development would increase the supply of residential housing units and other forms of real estate assets. Studies by Olanrele, Said, Daud, and Ab Majid, (2019) and Gumbs (2001) made case for the deployment of REITs in real estate development. The study by Olanrele et al. (2019) assessed the option of using REITs to finance real estate development directly within the current REIT legislation requirements in Nigeria. The legislation provides that $75 \%$ of REIT fund should be invested in direct real estate 
DOI: $\underline{10.51386 / 25815946 / \mathrm{ijsms}-\mathrm{v} 4 \mathrm{i} 5 \mathrm{p} 118}$

Volume: 4 Issue: 5

September to October 2021

https://www.ijsmsjournal.org

acquisition, while $25 \%$ is invested in real estate related assets. Asset allocation principle of the modern portfolio theory based on the Markowitz efficient frontier model was used to propose alternative asset allocation options for the Nigeria REIT. Results show that the REITs finance structure be; real estate purchase, 70\%; construction finance, 20\%; and 10\% financial deposit. The study recommended that the existing Nigeria REIT legislation be amended to promote REIT investment into direct real estate development in order to boost property stock.

Gumbs (2001) thesis studied the practicability of the REIT structure for real estate development process. The key objectives of the study were to; appraise the application of REIT structure by development companies and the factors governing their decisions as regards investment and creation of share holder value; and to explore the potential of the REIT format beyond passive real estate ownership to development-oriented public companies. The study reviewed previous studies on the effect on REIT performance, industry articles and development-oriented REITs companies were profiled. Findings from the study show that development oriented REITs implement tactics that concentrate on creating and adding value via real estate development. Besides real estate development, REIT-developers may engage in joint business enterprises with funds suppliers or private developers with particular skill, acquisition and disposition of assets, solicitation of funds, and share acquisitions. The study surmised that the REIT structure is an efficient catalyst for real estate development; and it is feasible for developers to achieve their objectives within the ambit of the REIT legislative and regulatory framework.

\section{Portfolio diversification benefit}

Diversification is the process of distributing capital among different forms of investment within a given portfolio. The fundamental essence of diversification is to minimize risk and maximize return. Real estate investment portfolio includes direct property investment and indirect property investment in the form of financial instruments. Real estate portfolio diversification seeks to minimize property-specific risks and maximize returns. Real estate diversification strategy could be by property type (sector), geographic region, and sources of return (Anderson, Benefield, and Hurst, 2015; National, Wee, Ebrahim, 2002; Eichholtz, Hoesli, MacGregor, and Nanthakumaran, 1995). Geographical diversity is defined as administrative area; the different sectors of real estate investment include; office property, retail property, different forms of residential properties, warehouses, hotels, etc. Property portfolio diversification based on sources of return can be classified based on typology suggested by the National Council of Real Estate Investment Fiduciaries, NCREIT into 'core' property (Strategic rental investment property), which represents the main sectors of commercial property market: retail property, office space, logistic centres, warehouses, hotel facilities and residential apartment building; the second classification is the 'value added' property (property development) which has the potential to increase in value with average volatility and whose profitability is largely determined by the value-added effect. Examples are the main property types including hospital facilities, dormitories, nursing homes and recreational facilities (Smietana, 2014).

The third classification is the 'opportunistic' property (speculative property) described as special purpose property that are subject to speculative development investments held for trading or leasing and land development projects. There is a strong positive between sector (property-type) and return on real estate assets, and return on equity. Return on the asset increases with the extent of diversification. Furthermore, diversified REITs operate and trade above specialized REITs. The practice of diversification has the potential to generally improve real estate portfolio performance and could be very huge prospects for the Nigeria REITs (Anderson et al., 2015; Smietana, 2014; National et al., 2002; and Eichholtz et al., 1995).

\section{Other prospects}

Other identified prospects of REITs in literature include economic growth, new pool of real estate investors, and low cost of fund. The development and growth of the real estate sector in an economy have a multiplier effect on the economy as the sector engages a multi and diverse activities and stakeholders. The REIT regime in US, UK, and Australia have helped to bolster economic growth and development of these nations. In Asia, Atchison and Yeung (2014) investigated the social and economic benefits of REITs in some countries such as Japan and Singapore - these were the earliest REIT markets in Asia. Others are Hong Kong, Malaysia, 
DOI: $\underline{10.51386 / 25815946 / \mathrm{ijsms}-\mathrm{v} 4 \mathrm{i} 5 \mathrm{p} 118}$

Volume: 4 Issue: 5

September to October 2021

https://www.ijsmsjournal.org

South Korea, Taiwan, and Thailand. These benefits range from job creation, adoption of best practices, positive impact on property cycles, real estate innovation, increasing transparency, and improving asset management.

REIT-Developers can engage in new development projects which generate real economic output and create new jobs in areas such as investment appraisal, REIT management, asset management, legal and trustee services, development management, construction, and investment banking. Through asset relocating, refurbishments and other enhancements, REITs are regularly associated with improving the quality of real estate assets which translates to healthier environments for tenants and for the society at large. REITs also support the healthy development of the property industry by improving market transparency. Being a listed instrument, they are needed to provide comprehensive information to shareholders about capital and rental values as well as occupancy rates and tenant mix, thus improving the capacity of all industry participants to plan effectively and assisting to smooth out real estate cycles. Finally, REITs benefit from relatively low cost of capital because of some factors, including liquidity, authorized dividends, tax concessions, and a lower perceived risk profile due to limits on development risk and borrowing (Atchison and Yeung, 2014).

In summary, the external factors influencing the growth, development and performance of the REIT structure are; political risk, social risks, strategic property location, investors' behaviour, property maintenance, tax treatment, property management (internal \& external), increase in rental value, infrastructure development, attraction to foreign investors. On the other hand the prospects of real estate investment trusts are hedge against inflation, superior dividend and earnings, increased liquidity, source of finance for real estate development, portfolio diversification, increased property supply, new pool of real estate investors, economic growth and low cost of fund. The external factors influencing the growth, development, and performance of REIT structure form the variables designed for investigating the challenges of the N-REITs as a viable option for real estate development projects in Nigeria.

\section{RESEARCH METHODOLOGY}

The area of the study is Abuja. Abuja officially replaced Lagos as the capital of Nigeria in December 1991, after 15 years of planning and construction. Physically located in the centre of the country and viewed as neutral geographical space both ethnically and religiously, it is where culture and religion meet. A large hill known as Aso Rock provides the backdrop for the city's government district, which is laid out along three axes representing the executive, legislative, and judicial branches. The enactment of decree No. 6, of 1976 leading to the establishment of a new Federal Capital promoted the naming of the region. It was named Abuja after a nearby village, which name was later changed to Suleija.

The new capital which was to be a symbol of Nigeria's aspirations for unity and greatness was carved out from Niger, kwara (now Kogi) and Plateau (now Nassarawa) States. It has a total land area of 8,000 square kilometers, which is more than twice the land area of Lagos State. The city was to be built in four (4) phases, the first schedule to commence in 1979 and provide space for 230,000 inhabitants across 4,000 hectares of land. The capital was scaled to have over a population of 1,600,000 and expandable at its sides to 3,200,000 with "Central Area" as the city centre. The later was structured in terms of rectal-near super blocks that would have two wings at its sides that can enclose a total of eight essentially self-contained "development sector" as the Master Plan calls them, with between 120,000 and 190,000 inhabitants each. The Territory is currently made up of six local councils, comprising the Abuja Municipal Council and five Local Government Areas, namely; Abaji, Gwagwalada, Kuje, Bwari and Kwali (fcda.gov.ng; Abuja city.com). 
DOI: $\underline{10.51386 / 25815946 / \mathrm{ijsms}-\mathrm{v} 4 \mathrm{i} 5 \mathrm{p} 118}$

Volume: 4 Issue: 5

September to October 2021

https://www.ijsmsjournal.org

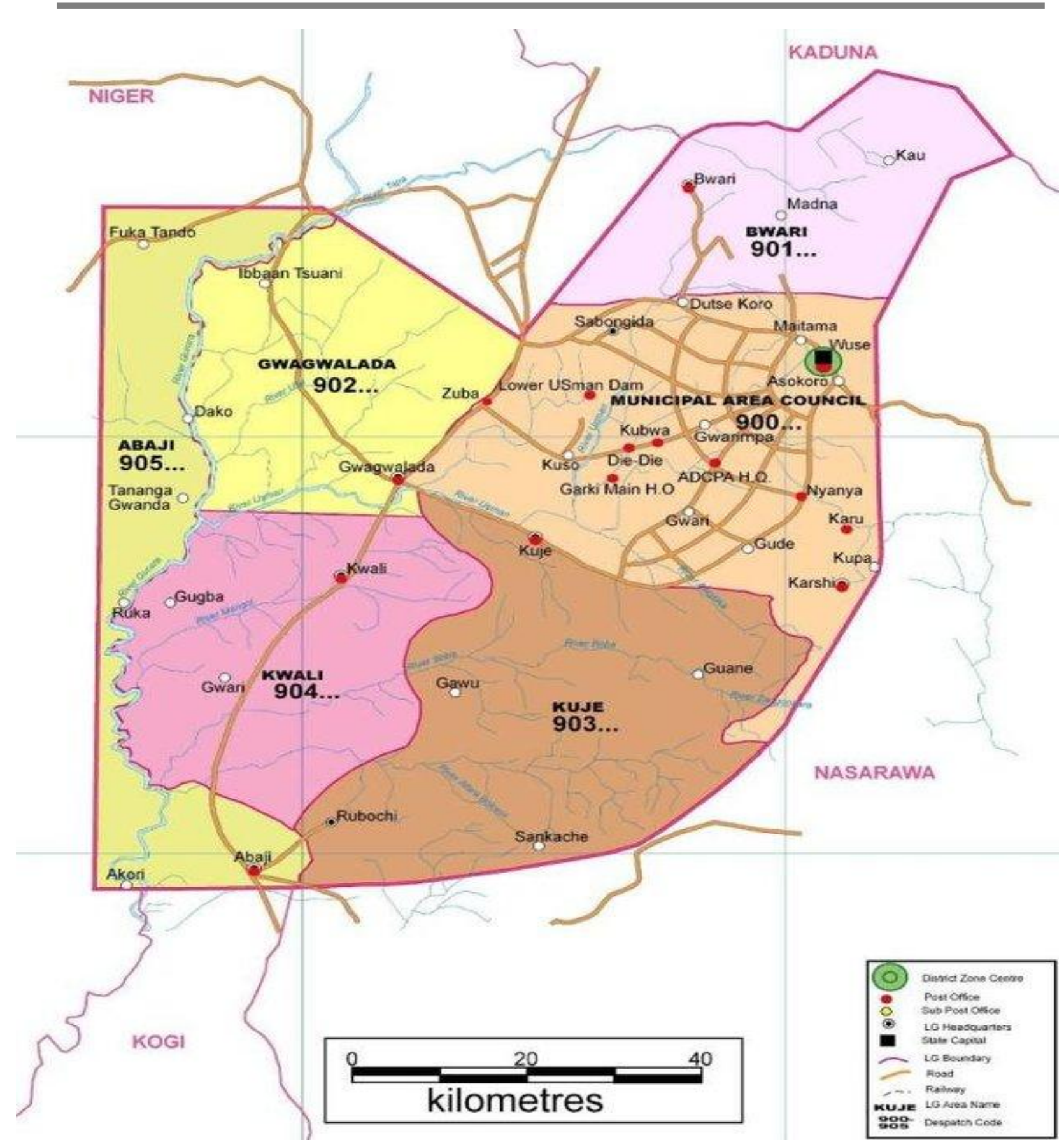

Fig. 1.1: Map of Abuja FCT showing the six area councils.

Source: Google (Uploaded by Sylvester Abomeh Ofobruku)

In recent times, the city of Abuja has witnessed rapid urbanization - being the seat of power. It is adjudged the fastest growing city in the country. People from different parts of the country migrate to Abuja to look for white-collar jobs and other forms of unskilled labour. This development has led to the increase in demand for residential accommodation and commercial space. There is large concentration of real estate development firms as a result of the demand for residential and commercial properties. Government regulatory agencies such as the Nigeria Stock Exchange and Securities and Exchange Commission are located in Abuja. 
DOI: $\underline{10.51386 / 25815946 / \mathrm{ijsms}-\mathrm{v} 4 \mathrm{i} 5 \mathrm{p} 118}$

Volume: 4 Issue: 5

September to October 2021

https://www.ijsmsjournal.org

This paper adopts a survey approach. Primary data were sourced from Real Estate Developers and Senior Staff Members of Securities and Exchange Commission (SEC) in Abuja. A sample of 275 stakeholders, comprising 221 Real Estate Developers and 54 Senior Staff members of Securities and Exchange Commission (SEC) were conveniently selected for the investigation. The instrument of data collection was structured questionnaire designed in line with the specific objectives of the paper. The questions were divided into sections. Two sets of questionnaire were designed for real estate developers and fund regulators (SEC). The questionnaires contain both open-ended and close-ended questions with mostly five-point Likert scale; strongly disagree, disagree, neutral, agree, strongly agree and few "Yes", "No" and "Not sure" questions. A pre-test of the instrument was conducted by administering certain number of questionnaire to the respondents to ascertain the suitability and reliability of the instrument. The reliability of the test instrument was determined using Cronbach's Alpha which yielded a correlation coefficient of 0.961 .

The questionnaires were delivered to the respondent which gave the researcher opportunity to discuss the objectives and the nature of the study with the respondents. The questionnaire was dropped and collected on a later date. Between the times the questionnaire was dropped and the time it was collected, follow up actions were taken; which include making calls and revisiting the respondents to ensure that they act on the questionnaire.

Data collected and collated was coded and analysed with the aid of statistical package for social sciences (SPSS) version 23. Descriptive statistics were used to analyse the responses. Frequency, percentages, means and standard deviation were used. In analyzing the challenges in adopting N-REIT structure for real estate development, the external factors were classified into nine (9) sub-groups: Investor's behaviour, Tax treatment, Increase in rental value, Infrastructure development, Strategic property location, Property maintenance, Attraction to international investors, Political risks, and Social Risks (Adapted from Olanrele, 2016). The questionnaire was administered to the senior staff of SEC. The questions were designed using 5 point Likert scale: Strongly agree $=5$, Agree $=4$, Undecided $=3$, Disagree $=2$, and Strongly disagree $=1$. The responses were analysed using mean and standard deviation. Questions were designed to elicit information from the fund regulators on the prospects of N-REITs as a finance option for real estate development in Nigeria. The prospects are increased returns on investment, ROI, tax benefit, liquidity in real estate sector, increased supply of real properties, hedge against inflation, portfolio diversification, source of finance for real estate development, new pool of investors, and low cost of funds. The questions were designed using 5 point Likert scale: Strongly agree $=5$, Agree $=4$, Undecided $=3$, Disagree $=2$, and Strongly disagree $=1$. The responses were analysed using mean and standard deviation. The mean criterion mark is three (3); which implies that any internal factor or prospects which mean score is above three and above is significant.

\section{RESULTS AND DISCUSSION Results}

The questionnaires administered were 275 copies. Real estate developers, 221, and 54 for Senior Staff of Securities and Exchange Commission, 217 were returned by real estate developers, and 52 by Senior Staff of SEC; giving total response rate of $97.82 \%$ return rate. The responses received were recorded and analysed using the statistical software SPSS (Statistical Package for the Social Sciences) version 23. The analysis conducted in this research concentrated mainly on obtaining frequency and percentage shares of the answers. Both description and analysis of the results are supported by presentation in the form of tables and chart.

Table 1: Questionnaire distribution and response rate

\begin{tabular}{llll}
\hline Stakeholders & Questionnaire distribution & Response Rate & Percentage \\
\hline Real Estate Developers & 221 & 217 & 78.91 \\
Fund Regulators & 54 & 52 & 18.91 \\
Total & 275 & 269 & 97.82 \\
\hline
\end{tabular}

In the questionnaire distribution and rate of response; 221 and 54 questionnaires were distributed to real estate developers and fund regulators respectively. 217 and 52 real estate developers and fund regulators responded giving $78.91 \%$ and $18.91 \%$ respectively of the total response rate $(97.82)$. The high response rate is an indication that the respondents are willing to participate in the survey and they also understood the questions contained in the questionnaire very well. 
DOI: $\underline{10.51386 / 25815946 / \mathrm{ijsms}-\mathrm{v} 4 \mathrm{i} 5 \mathrm{p} 118}$

Volume: 4 Issue: 5

September to October 2021

https://www.ijsmsjournal.org

Presentation of results from the study questionnaire administered to the real estate developers in Abuja

Table 2 shows the demography of the real estate developers. Under gender, $165(76 \%)$ of the respondents are male while $52(24 \%)$ are female. On age, 21-30, $9(4 \%), 31-40,37(17 \%), 41-50,128(59)$, and > 50, 43 (20\%). On highest educational qualification, $0(0 \%)$ have OND, $6(3 \%)$ have HND, $122(56 \%)$ have B.Sc/B.Tech, 76 (35\%) have M.Sc/M.Tech, 13 (6\%) have P.hD. For working experience, $0(0 \%)$ have 1-5 years working experience, $41(19 \%)$ have 6-10, 80 (37\%) have 11-15, $61(28 \%)$ have 16-20, and $35(16 \%)$ have above 20. On position, Chief Executive Officer, 19 (9\%), Managing Director, 80 (37\%), Director, 89 (41\%), and Chief Operating Officer, $28(13 \%)$. The analysis indicates that the real estate developers are highly qualified to provide information for the administered questionnaire: they have experience, adequate qualification, and they are in the top management positions of the firms.

Table 2: Demography of the respondents

\begin{tabular}{cccc}
\hline Characteristics & Options & Frequency & Percentage \\
\hline Gender & Male & 165 & 76 \\
Age (Years) & Female & 52 & 24 \\
& $21-30$ & 9 & 4 \\
& $31-40$ & 37 & 17 \\
Highest Qualification & $41-50$ & 128 & 59 \\
& $>50$ & 43 & 20 \\
& OND & 0 & 3 \\
Work Experience (Years) & HND & 6 & 56 \\
& B.Sc/B.Tech & 122 & 35 \\
& M.Sc/M.Tech & 76 & 6 \\
Position & $1-5$ & 13 & 0 \\
& Ph.D & 0 & 19 \\
& $11-10$ & 41 & 37 \\
& $16-20$ & 80 & 28 \\
& Above 20 & 61 & 16 \\
& Chief Executive Officer & 35 & 9
\end{tabular}

Table 3: Sources of real estate development finance in Nigeria

\begin{tabular}{lcc}
\hline & Frequency & Percent \\
\hline Equity capital & 102 & 47.5 \\
Commercial banks & 56 & 26.2 \\
Mortgage banks & 35 & 16.3 \\
Development banks & 15 & 6.7 \\
Insurance companies & 5 & 2.1 \\
Pension funds & 4 & 1.2 \\
Micro finance banks & 0 & 0.0 \\
Capital market & 0 & 0.0 \\
CMBS & 0 & 0.0 \\
Real estate crowd funding & 0 & 0.0 \\
\hline
\end{tabular}

Source: Field Survey 2020 
DOI: $\underline{10.51386 / 25815946 / \mathrm{ijsms}-\mathrm{v} 4 \mathrm{i} 5 \mathrm{p} 118}$

Volume: 4 Issue: 5

September to October 2021

https://www.ijsmsjournal.org

Table 3 shows that frequency of the various sources of development finance in Nigeria. Equity capital 102 (47.8\%), commercial banks $56(26.2 \%)$, mortgage banks $35(16.5 \%)$, development banks $15(6.9 \%)$, insurance companies $5(2.1 \%)$, pension funds $4(1.9 \%)$, micro finance banks $0(0.0 \%)$, capital markets $0(0.0 \%)$, CMBS 0 $(0.0 \%)$, and real estate crowdfunding $0(0.0 \%)$. At a glance, the table shows that equity capital is the highest source of development finance in Nigeria, hence the limited number of real estate stock in Nigeria.

Table 4: Types of properties developed by real estate developers

\begin{tabular}{ccc}
\hline Type of property & Frequency & Percentage \\
\hline Retail & 106 & 39.28 \\
Office Space & 174 & 64.49 \\
Industrial & 22 & 8.15 \\
Hotel & 46 & 17.05 \\
Residential & 203 & 75.24 \\
Hospital & 19 & 7.04 \\
Plantation & 2 & 0.74 \\
Total & 572 & 212 \\
\hline
\end{tabular}

Table 4 Shows that $106(39.28 \%)$ of real estate developers develop retail properties, $174(64.49 \%)$ develop office spaces, $22(8.15 \%)$ develop industry, 46 (17.05\%) develop industrial, 203 (75.24\%) develop residential, $19(7.04 \%)$ develop hospital, and $2(0.74)$ develop plantation. The table provides evidence that majority of the developers engage in residential, retail office space development.

Table 5: Awareness of REIT by real estate developers

\begin{tabular}{ccc}
\hline Responses & Frequency & Percentage \\
\hline Yes & 106 & 49 \\
No & 78 & 36 \\
Not sure & 33 & 15 \\
Total & 217 & 100 \\
\hline
\end{tabular}

Table 5 shows that 106 (49\%) of real estate developers are aware of REIT, 78 (36\%) are not, while 33 $(15 \%)$ are not sure. More than half of the developers are not aware of REIT. This is an indication that REIT is not popular amongst real estate developers.

Table 6: Real Estate Developers that invest in REIT

\begin{tabular}{ccc}
\hline Responses & Frequency & Percentage \\
\hline Yes & 8 & 3.69 \\
No & 209 & 96.31 \\
Unsure & 0 & 0 \\
Total & 217 & 100 \\
\hline
\end{tabular}

Table 6 shows that $8(3.69 \%)$ of developers invest in N-REITs, 209 (96.31\%) do not invest in N-REITs, while none is unsure. The number of developers that invest in REIT is very infinitesimal an indication that they could not be informed of the N-REITs.

Table 7: Response on N-REIT as a viable option for development finance

\begin{tabular}{ccc}
\hline Responses & Frequency & Percentage \\
\hline Strongly disagree & 9 & 4 \\
Disagree & 48 & 22 \\
Neutral & 61 & 28 \\
Agree & 84 & 39 \\
Strongly agree & 15 & 7 \\
Total & 217 & 100 \\
\hline
\end{tabular}


DOI: $\underline{10.51386 / 25815946 / \mathrm{ijsms}-\mathrm{v} 4 \mathrm{i} 5 \mathrm{p} 118}$

Volume: 4 Issue: 5

September to October 2021

https://www.ijsmsjournal.org

Table 7 shows that $9(4 \%)$ of real estate developers strongly agree that N-REIT is a viable option for development finance, 48 (22\%) disagree, 61 (28\%) are neutral, 84 (39\%) agree, while 15 (7\%) strongly agree. The percentage of developers that agree that N-REITs are viable option for development finance is higher than those that disagree, an indication that there are prospects for N-REITs as a viable option for real estate development finance.

Table 8: Responses on intention to establish REIT company

\begin{tabular}{ccc}
\hline Responses & Frequency & Percentage \\
\hline Yes & 52 & 24 \\
No & 59 & 27 \\
Not sure & 106 & 49 \\
Total & 217 & 100 \\
\hline
\end{tabular}

Table 8 shows that $52(24 \%)$ of real estate developers are willing to establish REIT company, $59(27 \%)$ are not willing, while $106(49 \%)$ are not sure.

Question number nine is an open-ended question. The respondents were asked the reasons that influence their intention to establish REIT company or not. Majority of the firms said they don't understand how the REIT structure operates but after explaining to them about the operations of the REIT structure and the immense advantages it enjoys over other sources of finance, majority of the responders concurred that it could be a viable source for real estate development and that they are willing to establish REIT companies if guided properly.

Presentation of results from the study questionnaire administered to fund regulators in Abuja

Table 9: Demography of fund regulators

\begin{tabular}{|c|c|c|c|}
\hline Characteristic & Options & Frequency & Percentage \\
\hline \multirow[t]{2}{*}{ Gender } & Male & 39 & 75 \\
\hline & Female & 13 & 25 \\
\hline \multirow[t]{3}{*}{ Staff Category } & Senior staff & 41 & 79 \\
\hline & Intermediate & 11 & 21 \\
\hline & Junior Staff & 0 & 0 \\
\hline \multirow[t]{2}{*}{ Education Background } & Real estate & 5 & 9.62 \\
\hline & Non real estate & 47 & 90.38 \\
\hline \multirow[t]{5}{*}{ Highest education qualification } & OND & 0 & 0 \\
\hline & HND & 5 & 9.62 \\
\hline & B.Sc/B.Tech & 29 & 55.77 \\
\hline & M.Sc/M.Tech & 15 & 28.85 \\
\hline & Ph.D & 3 & 5.77 \\
\hline \multirow[t]{7}{*}{ Number of years in service } & $1-5$ & 0 & 0 \\
\hline & $6-10$ & 4 & 7.69 \\
\hline & $11-15$ & 9 & 17.31 \\
\hline & $16-20$ & 17 & 32.69 \\
\hline & $21-25$ & 13 & 25.00 \\
\hline & $26-30$ & 7 & 13.46 \\
\hline & Above 30 & 2 & 3.85 \\
\hline
\end{tabular}

Table 9 shows that under gender, $39(75 \%)$ of the respondents are male while $13(25 \%)$ of the respondents are female. On staff category, $41(79 \%)$ are senior staff, $11(21 \%)$ are intermediate staff, and $0(0 \%)$ junior staff. On highest educational qualification, $0(0 \%)$ has OND, $5(9.62 \%)$ has HND, $29(55.77 \%)$ have B.Sc/B.Tech, 15 (28.85\%) have M.Sc/M.Tech, while $3(3.85 \%)$ have Ph.D. On number of years in service, $0(0 \%)$ have served for $1-5$ years, $4(7.69 \%)$, have served for 6 - 10 years, $9(17.31 \%)$ have served for $11-15$ years, $17(32.69 \%)$ have served for 16 - 20 years, $13(25.00 \%)$ have served for $21-25$ years, $7(13.46 \%)$ have served for $26-30$ 
DOI: $\underline{10.51386 / 25815946 / \mathrm{ijsms}-\mathrm{v} 4 \mathrm{i} 5 \mathrm{p} 118}$

Volume: 4 Issue: 5

September to October 2021

https://www.ijsmsjournal.org

years, and $2(3.85 \%)$ have served for above 30 years. The above demographic statistics of the respondents show that they are experienced and knowledgeable in the workings of fund regulations that relate to the money and capital markets.

Table 10 below shows that $2(3.8 \%)$ of the fund regulators (SEC Senior Staff) strongly disagree that political risks influence the future growth and development of the N-REITs, $4(7.7 \%)$ disagree, $0(0.0)$ undecided, 28 (53.8) agree, while 18 (34.6) strongly agree. A high mean response 4.43 greater than the criterion mean of 3 confirms that political factor influences the future growth and development of the N-REITs. A standard deviation of 1.12 which is close to the mean shows relatively high consistency of responses. The mean responses of other factors; Strategic property locations (4.43 \pm 0.82$)$, investors' behaviour $(3.98 \pm 0.97)$,

Table 10: External factors influencing performance, growth and development of N-REITs

\begin{tabular}{|c|c|c|c|c|c|c|}
\hline Factors & $\begin{array}{l}\text { Strongly } \\
\text { disagree } \\
\text { n }(\%)\end{array}$ & $\begin{array}{l}\text { Disagree } \\
\text { n }(\%)\end{array}$ & $\begin{array}{l}\text { Undecide } \\
\text { d } \\
\text { n }(\%)\end{array}$ & $\begin{array}{l}\text { Agree } \\
\text { n }(\%)\end{array}$ & $\begin{array}{l}\text { Strongly } \\
\text { agree } \\
\text { n }(\%)\end{array}$ & Mean \pm SD \\
\hline Political risks & $2(3.8)$ & $4(7.7)$ & $0(0.0)$ & $28(53.8)$ & $18(34.6)$ & $4.10 \pm 1.12$ \\
\hline Strategic property locations & $0(0.0)$ & $0(0.0)$ & $2(3.8)$ & $27(51.9)$ & $23(44.2)$ & $4.43 \pm 0.82$ \\
\hline Investors' behaviour & $1(1.9)$ & $4(7.7)$ & $5(9.6)$ & $32(61.5)$ & $10(19.2)$ & $3.98 \pm 0.97$ \\
\hline Property maintenance & $0(0.0)$ & $2(3.8)$ & $3(5.8)$ & $25(48.1)$ & $22(42.3)$ & $4.02 \pm 1.01$ \\
\hline Tax treatment & $0(0.0)$ & $0(0.0)$ & $2(3.8)$ & $33(63.5)$ & $17(32.7)$ & $4.34 \pm 0.78$ \\
\hline Increase in rental value & $0(0.0)$ & $2(3.8)$ & $5(9.6)$ & $15(28.8)$ & $30(57.7)$ & $4.15 \pm 1.21$ \\
\hline Infrastructure development & $3(5.8)$ & $1(1.9)$ & $4(7.7)$ & $25(48.1)$ & $19(36.5)$ & $4.00 \pm 1.21$ \\
\hline $\begin{array}{l}\text { Attraction to international } \\
\text { investors }\end{array}$ & $5(9.6)$ & $10(19.2)$ & $17(32.7)$ & $15(28.8)$ & $5(9.6)$ & $2.11 \pm 0.88$ \\
\hline Social risks & $1(1.9)$ & $11(21.2)$ & $14(26.9)$ & $19(36.5)$ & $7(15.5)$ & $3.77 \pm 0.83$ \\
\hline
\end{tabular}

Source: Field survey 2020

property maintenance $(4.02 \pm 1.01)$, tax treatment $(4.34 \pm 0.78)$, increase in rental value $(4.15 \pm 1.21)$, infrastructure development $(4.00 \pm 1.21)$ and social risks $(3.77 \pm 0.83)$ are above the criterion mean of 3 , showing that all the factors influence performance, future growth and development of N-REITs. Attraction to international investors mean is $(2.11 \pm 0.78)$, which is below the criterion mean of 3 . This is an indication that attraction to international investors does not influence the future growth and development of N-REITs. In summary all the above listed external factors influence the future growth and development of N-REITs except attraction to international investors.

Table 11: Responses on Nigerian property market performing well

\begin{tabular}{lcc}
\hline \multicolumn{1}{c}{ Responses } & Frequency & Percentage \\
\hline Strongly disagree & 3 & 5 \\
Disagree & 33 & 64 \\
Neutral & 10 & 19 \\
Agree & 6 & 12 \\
Strongly agree & 0 & 0 \\
Total & 52 & 100 \\
\hline
\end{tabular}

Table 11 shows that, $3(5 \%)$ of the fund regulators strongly disagree that Nigerian property market is performing well, $33(64 \%)$ disagree, $10(19 \%)$ are neutral, $6(12 \%)$ agree, while $0(0 \%)$ strongly agree. 
DOI: $\underline{10.51386 / 25815946 / \mathrm{ijsms}-\mathrm{v} 4 \mathrm{i} 5 \mathrm{p} 118}$

Volume: 4 Issue: 5

September to October 2021

https://www.ijsmsjournal.org

Table 12: Responses on N-REIT market performing well

\begin{tabular}{lcc}
\hline \multicolumn{1}{c}{ Responses } & Frequency & Percentage \\
\hline Strongly disagree & 5 & 9 \\
Disagree & 36 & 69 \\
Neutral & 10 & 20 \\
Agree & 1 & 2 \\
Strongly agree & 0 & 0 \\
Total & 52 & 100 \\
\hline
\end{tabular}

Table 12 shows that, $5(9 \%)$ of the fund regulators strongly disagree that N-REIT market is performing well, $36(69 \%)$ disagree, $10(20 \%)$ are neutral, $1(2 \%)$ agrees, while $0(0 \%)$ strongly agree.

Table 13 below shows that $6(12 \%)$ of fund regulators strongly disagree that N-REITs yields are attractive compared to other investments, $33(63 \%)$ disagree, $8(15 \%)$ are neutral, $5(10 \%)$ agree, while $0(0 \%)$ strongly agree.

Table 13: Acceptability of N-REIT regulation in Nigeria

\begin{tabular}{lcc}
\hline Responses & Frequency & Percentage \\
\hline Strongly disagree & 6 & 12 \\
Disagree & 33 & 63 \\
Neutral & 8 & 15 \\
Agree & 5 & 10 \\
Strongly agree & 0 & 0 \\
Total & 52 & 100 \\
\hline
\end{tabular}

Table 14: Prospects of Real Estate Investment Trusts in Nigeria

\begin{tabular}{|c|c|c|c|c|c|c|}
\hline Factors & $\begin{array}{l}\text { Strongly } \\
\text { disagree } \\
\text { n }(\%)\end{array}$ & $\begin{array}{l}\text { Disagree } \\
\text { n }(\%)\end{array}$ & $\begin{array}{l}\text { Undecided } \\
\text { n }(\%)\end{array}$ & $\begin{array}{l}\text { Agree } \\
\mathbf{n}(\%)\end{array}$ & $\begin{array}{l}\text { Strongly } \\
\text { agree } \\
\text { n (\%) }\end{array}$ & Mean \pm SD \\
\hline Tax benefit & $4(7.7)$ & $6(11.5)$ & $4(7.7)$ & $28(53.8)$ & $10(19.2)$ & $3.65 \pm 1.29$ \\
\hline $\begin{array}{l}\text { Increased returns on } \\
\text { investment }\end{array}$ & $4(7.7)$ & $8(15.4)$ & $5(9.6)$ & $25(48.1)$ & $8(15.4)$ & $3.37 \pm 1.15$ \\
\hline $\begin{array}{l}\text { Liquidity in real estate } \\
\text { sector }\end{array}$ & $4(7.7)$ & $6(11.5)$ & $7(13.5)$ & $20(38.5)$ & $15(28.8)$ & $3.69 \pm 1.22$ \\
\hline $\begin{array}{l}\text { Increased supply in real } \\
\text { properties }\end{array}$ & $2(3.8)$ & $4(7.7)$ & $1(1.9)$ & $25(48.1)$ & $20(38.5)$ & $4.1 \pm 1.02$ \\
\hline Hedge against inflation & $9(17.3)$ & $10(19.2)$ & $15(28.8)$ & $15(28.8)$ & $3(5.8)$ & $2.87 \pm 1.18$ \\
\hline Portfolio diversification & $2(3.8)$ & $5(9.6)$ & $5(9.6)$ & $25(48.1)$ & $15(28.8)$ & $3.88 \pm 1.10$ \\
\hline $\begin{array}{l}\text { Source of finance for real } \\
\text { estate development }\end{array}$ & $6(11.5)$ & $20(38.5)$ & $15(28.8)$ & $10(19.2)$ & $1(1.9)$ & $2.62 \pm 0.97$ \\
\hline New pool of investors & $4(7.7)$ & $5(9.6)$ & $4(7.7)$ & $32(61.5)$ & $7(13.5)$ & $3.63 \pm 1.15$ \\
\hline Low cost of fund & $2(3.8)$ & $12(23.1)$ & $30(57.7)$ & $6(11.5)$ & $2(3.8)$ & $2.88 \pm 0.64$ \\
\hline
\end{tabular}

Source: Field survey 2020

Table 14 shows that $4(7.7 \%)$ of the fund regulators (SEC Senior Staff) strongly disagree that tax benefit is a prospect REITs of Nigeria, 6 (11.5\%) disagree, 4 (7.7) undecided, 28 (53.8) agree, while 10 (19.2) strongly agree. A mean response 3.65 greater than the criterion mean of 3 confirms that tax benefit is a prospect of Nigeria REITs. A standard deviation of 1.29 which is close to the mean shows relatively high consistency of responses. The mean responses of other prospects; increased returns on investment $(3.37 \pm 1.15)$, liquidity in real estate sector $(3.69 \pm 1.22)$, increased supply in real property $(4.1 \pm 1.02)$, hedge against inflation $(2.87 \pm$ $1.18)$, portfolio diversification $(3.88 \pm 1.10)$, source of finance for real estate development $(2.62 \pm 0.97)$, new 
DOI: $\underline{10.51386 / 25815946 / \mathrm{ijsms}-\mathrm{v} 4 \mathrm{i} 5 \mathrm{p} 118}$

Volume: 4 Issue: 5

September to October 2021

https://www.ijsmsjournal.org

pool of investors $(3.63 \pm 1.15)$, and low cost of funds $(2.88 \pm 0.64)$. The mean score for the following prospects; hedge against inflation, source of finance for real estate development, and low cost of fund were below the criterion mean of 3 . An indication that these were not considered prospects by the fund regulators. Apart from these three variables, others are prospects of real estate investment trust in Nigeria.

\section{DISCUSSION AND IMPLICATION OF RESULTS}

Through literature review, various sources of development finance were identified and they include: equity capital, commercial banks, mortgage banks, development banks, insurance companies, pension funds, micro finance banks, capital market, CMBS, and real estate crowd funding. Table 3 shows that the highest source of funding real estate development in Nigeria is through equity fund, followed by commercial banks. The implication of this result is that equity capital is grossly inadequate for real estate development given that real estate development is capital intensive. The percentage contribution of commercial bank in the real estate development sector is quite small and the reason is that loan tenor for commercial bank is short ( $1-5$ years), also the interest rate is very high thereby discouraging developers from sourcing for substantial fund through that source. Inadequate funding is the major reason we have low stock of real estate in Nigeria. Another issue is low development diversification in types of real estate as evidenced in table 4 which shows that a high percentage of the developers engage in residential properties, followed by office space, and retail. Very few develop industrial, hotel, hospital and plantation. The few that engage in these properties are sole proprietors and which is the reason there are very limited number of five star hotels in Nigeria if at all there is any. In the US for instance, the real estate sector is so developed that they have Hotel REITs - that is REIT structure that strictly invest in hotels. There is also the issue of housing shortage in Nigeria which has also been attributed to inadequate funding and the bureaucratic bottlenecks attendant with sourcing development fund from the contemporary sources of development finance.

The study by Ogedengbe and Adesopo (2003) also found similar results with this study; the highest source of development fund is the internal source which is also akin to equity capital, followed by commercial banks and mortgage. The study in the analysis didn't include pension funds, micro finance banks, CMBS and real estate crowd funding. They opined bureaucracy and excessive protocol, loan ceiling and duration, collateral security and high interest rate and restrictive government policies are factors that hampering securing funds from financial institutions. In summary, equity capital, commercial banks and mortgage banks are the main sources of development finance in Nigeria. Funds from these sources are grossly inadequate to embark on massive real estate development projects in Nigeria. Majority of the real estate developers in Abuja are not aware of the REIT structure; which is the reason why very few invest in it, albeit, many consider it as a viable option for funding real estate development project due to interaction with the investigators. Awareness of the REIT structure and its attendant benefits would have motivated the developers to come together and establish more REITs as we only have three REIT regimes in Nigeria. Having more REITs will boost fund availability for real estate development projects.

Challenges in adopting N-REIT as a viable option for financing real estate development projects are perceived as the external factors influencing the performance of N-REITs. Political risk, strategic property locations, investors' behaviour, property maintenance, tax treatment, increase in rental value, infrastructure development and social risks influence performance, growth and development according to the respondents (fund managers). The only factor that does not influence the N-REITs performance is attraction to international investors. A similar study by Olanrele (2016) confirms that external sub-factors such as political leadership/risk, investor's sentiment, infrastructure, security affect N-REIT yield.

Political risk generally influences investments. In stable political climate, business and investments flourish, but where there is political turmoil, it affects investment, although the N-REIT has shown that it has potential for growth and development, the market capitalisation is very low, which is the reason it is not recognised globally. Also the number (3) is very small as compared to other REIT regimes. In the stock market, in terms of trading volumes and increase in market share price, the performance of N-REIT has been very dismal. Equitable tax regime, infrastructure development generally helps to boost investment. In situations where there are multiple tax regimes or over taxation, low and decaying infrastructure development, investments are hampered, in this case the N-REITs. 
DOI: $\underline{10.51386 / 25815946 / \mathrm{ijsms}-\mathrm{v} 4 \mathrm{i} 5 \mathrm{p} 118}$

Volume: 4 Issue: 5

September to October 2021

https://www.ijsmsjournal.org

Results in table 14 show that fund managers perceived prospects of REITs in Nigeria are; tax benefit, liquidity in real estate sector, increase supply in property, portfolio diversification, increased return on investment, and new pool of investors. On the contrary, hedge against inflation, low cost of fund, and, most importantly, REIT as a source of finance for real estate development were not perceived as prospects. Whereas some of these findings conform to previous studies, others do not. For instance quite a number of empirical studies were not definite about whether REIT is a hedge against inflation. Though Erol and Tirtiroglu (2008) found out that Turkish REIT is a good hedge against inflation, extant literature is not definitive. The implication is that REIT could be or not be a good hedge against inflation depending on the prevailing economic circumstance. This explains why REIT was not considered a hedge against inflation because of the double digit inflation rate in Nigeria and other macroeconomic factors.

On the prospect of REIT as a source of finance for real estate development, fund regulators do not agree which is contrary to the position of the real estate developers who reasoned that REIT could be a viable finance option for real estate development. This could be explained by the fact that the fund regulators are conversant with the regulations guiding the operations of REIT more than the developers. Also the fund regulators position does not concur with the findings of Kamua (2016) in which $82 \%$ of developers agreed that REIT was a huge source of capital for different real property projects. This could explain the reason why the Kenya REIT has been recognised as part of the global REIT regime. On low cost of fund, fund regulators do not consider it a prospect contrary to the findings of Kamua (2016) and Atchison and Yeung (2014) that concurred that low cost of capital is a prospect of REIT. This can be explained based on the point of view of the fund regulators who might consider the cost of setting up an IPO to be high.

The results also show that increase supply of real property which scored highest (4.1), is a prospect of REIT in Nigeria. This is in tandem with the findings of Atchison and Yeung (2014) and Kamua (2016). This could be explained by the housing deficit and low real estate stock in Nigeria which REIT could address by engaging in direct real estate development.

\section{CONCLUSION}

The paper investigated the challenges and prospects of the Nigerian REIT structure as a viable option for real estate development financing. The study specifically assessed the factors influencing the growth, development and performance of N-REIT; and also the prospects of the N-REIT structure as a viable option for financing real estate development projects. Real estate development is a capital intensive venture. In Nigeria the major challenge facing real estate development is finance, hence the need to consider REITs as a viable option for development finance. The challenges encountered in sourcing for development finance are documented. In most other climes such as Kenya and South Africa, the REIT regimes is thriving and this is not the case in Nigeria. There are certain institutional and firm-specific factors that influence the performance, growth and development of N-REITs. Addressing some of these issues could make N-REIT a viable source for real estate development project in Nigeria given that there is low real estate stock in Nigeria evidenced by the magnitude of housing shortage in Nigeria. This study added to the body of literature on REIT especially in a developing country context such as Nigeria.

Having identified some factors hampering the deployment of N-REIT in financing real estate development, the following recommendations are made; awareness creation, review of the Investment and Securities Act, 2007, massive infrastructure development both at the state and national level, and building transparency in the business environment.

There is need to create awareness on the REIT structure as an investment tool. The authority at federal, state and local government should embark on mass sensitization of the public on the importance to establish REIT Company. REITs provide opportunities for the general public; both the high, medium and low income earners the opportunity to invest indirectly in real estate without going through the stress of direct real estate development. In the US and other countries, REITs provided the low income earners the opportunity to be shareholders in REIT firms. The REIT structure can help lift the populace from abject poverty. The REIT structure permits individuals to invest little amounts they can afford and become property owners by the virtue of owning shares. 
DOI: $\underline{10.51386 / 25815946 / \mathrm{ijsms}-\mathrm{v} 4 \mathrm{i} 5 \mathrm{p} 118}$

Volume: 4 Issue: 5

September to October 2021

https://www.ijsmsjournal.org

For N-REIT to aid real estate development there is need to review the Investment and Securities Act, 2007. The Act provides that $75 \%$ of the fund should be invested in direct real estate investment and $25 \%$ in other investments and securities. Anything outside this arrangement will attract corporate taxation from the authority. The Act does not permit the firm the firms to develop real estate. Furthermore, the Act stipulates that 90\% of REIT income generated from investment operations should be distributed to shareholders as dividend. Given our peculiar circumstances there is need to review the Act in order to accommodate real estate development with stringent conditions and guidelines. There is low housing stock or development that the REITs can acquire.

There is a correlation between business development and infrastructure development. A current example is China. Nigeria lack adequate social infrastructure to support investment most especially real estate development. The government should embark on massive infrastructural development through public-private partnership (PPP).Infrastructure development has a multiplier effects. Infrastructure provision will boost REIT performance, growth and development. As at now, there are only 3 registered REITs in Nigeria.

Transparency in business entails operating in a manner that is easy for investors to see what actions are performed. Transparency enhances investment/business of any organisation. A good transparency index for Nigeria will enhance the performance, growth and development of N-REIT. In the Global Real Estate Transparency Index 2018, Nigeria was ranked $67^{\text {th }}$ under low-transparent. The index covers 100 markets based on 186 indicators. These parameters are categorised into six sub-groups; market fundamentals, performance measurement, governance of list vehicles, regulatory, legal frame works, transaction process and environmental sustainability (JLL, 2018). Global Real Estate Transparency Index influences foreign investors on the market to move their funds. Nigeria improving on all the six areas will attract foreign investors to invest/establish REIT companies in Nigeria; which will invariably enhance performance, growth and development of N-REITs.

The study has made a noteworthy contribution in the aspect of real estate finance vis-à-vis the limited studies/paucity of literature on N-REIT. The recommendations, if implemented, by policy makers, fund managers, and real estate developers, will go a long way in addressing the challenges experienced in sourcing for real estate development funds by making REIT structure an alternative viable option for financing real estate development projects in Nigeria which will invariably increase the real estate stock in Nigeria and contribute immensely to the economic development of the nation. Notwithstanding, this paper has its limitation. The sample size and geographic coverage of the study is small which has the potential of negatively affecting the generalization of the results so established. Further studies should increase the sample size and geographic scope; and also critically appraise specifically the regulations guiding the operations of the N-REITS as enshrined in the Investment and Securities Act, 2007 as it affects funding real estate development.

\section{REFERENCES}

[1] Abdulai, R. (2013). Editorial: Real estate securitization and unitisation. Journal of International Real Estate and Construction Studies, vol. 3(1), pp. 1-5. Retrieved from https://search.proquest.com/openview/850ebe07d0e9a1445d2974eb8d55952d/1?pqorigsite $=$ gscholar $\& \mathrm{cbl}=2034838$

[2] Abujacity.com. (n.d.). Get to know - Abuja city guide. https://www.abujacity.com/get-to-know

[3] Ajibola, M. O., Olayede, S. A., \& Oni, A. O. E. (2009). Real estate investment trust: An attractive investment vehicle for real estate development in Nigeria. The Estate Surveyor and Valuer, vol. 32 (1), pp. 60-66.

[4] Alao, O. (2018, October 24). Wither REITs in Nigeria? An exposition on the challenges and prospects of real estate investment trusts in Nigeria. LinkedIn. https://www.linkedin.com/pulse/whither-reits-nigeria-exposition-challenges-prospects-olayinka-alao/

[5] Anderson, R. I., Benefield, J. D., and Hurst, M. E. (2015). Property-type diversification and REIT performance: An analysis of operating performance and abnormal returns. Journal of Economic and Finance, vol. 39(1), pp. 48-74. https://doi.org/10.1007/s12197

[6] Atchison. K, \& Yeung, V. S. (2014). The impact of REITs on Asian economies. Asian Pacific Real Estate Association Limited. Retrieved from http://www.aprea.asia/fi le/The\%20Impact\%20of\%20REITs\%20on\%20Asian\%20Economies.pdf

[7] Baum, A. (2008). Unlisted property funds: supplying capital to developing property markets? International Real Estate Research Symposium (IRERS 2008). Kuala Lumpur, Malaysia. 
DOI: $\underline{10.51386 / 25815946 / \mathrm{ijsms}-\mathrm{v} 4 \mathrm{i} 5 \mathrm{p} 118}$

Volume: 4 Issue: 5

September to October 2021

https://www.ijsmsjournal.org

[8] Baum, A., and Murray, C. (2010). Understanding the barriers to real estate investments in developing economies. International Real Estate Research Symposium (IRERS 2010). Kuala Lumpur, Malaysia.

[9] Blau, B. M., Nguyen, N., \& Whitby, R. J. (2015). The distribution of REIT liquidity. Journal of Real Estate Literature, vol. 23(2), pp. 233-257. https://doi.org/10.5555/0927-7544.23.2.233

[10] Bruegeman, W. B., \& Fisher, J. D. (2002). Real estate finance and investment (11 ${ }^{\text {th }}$ ed.). New York: McGraw Hill/Irwin

[11] Cannon, S. E., \& Cole, R. A. (2011). Changes in REIT liquidity 1988 - 2007: Evidence from daily data. Journal of Real Estate Finance and Economics, vol. 43, pp. 258-280. http://doi.org/10.1007/s11146-010-9270-3

[12] Clayton, J., \& Mackinnon, G. (2000). Measuring and explaining changes in REIT liquidity: Moving beyond the bid-ask spread. Real Estate Economics, vol 28(1), pp. 89-115. http://doi.org/10.1111/1540-6229-00794.

13] Christon, C., Gupta, R., Nyakabawo, W., \& Wohar, M. E. (2018). Do house prices hedge inflation in the US? A quantile cointegration approach. International Review of Economics \& Finance, vol. 54, pp. 15-26. https://doi.org/10.1016/j.iref.2017.12.012

[14] Chang, K.-L. (2017). Does REIT index hedge inflation risk? New evidence from the tail quantile dependences of the Markovswitching GRG copula. The North America Journal of Economics and Finance, vol. 39, pp. 56-67. https://doi.org/10.1016/j.najef.2016.11.001

[15] Eichholtz, P., Hoesli, M., MacGregor, B., \& Nanthakumaran, N. (1995). Real estate portfolio diversification by sources of return. Journal of Property Finance, vol. 6(3), pp. 39-59. http://doi.org/ 10.1108/09588689510101676

[16] Erol, I., \& Tirtiroglu, D. (2008). The inflation-hedging properties of Turkish REITs. Applied Economics, vol. 40(20), pp. 2671-2696. https://doi.org/10.1080/00036840600970237

[17] Federal Capital Development Authority (FCDA). (n.d.). The new federal capital - How it all started.https://www.fcda.gov.ng/about/thenew-federal-capita-Investment and Securities Act 2007. (Nig.).

[18] Jones Lang and Laselle. (2018). Global real estate transparency index $2018 . \quad$ Retrieved from https://www.greti.jil.com/greti/rankings.

[19] Kamau, K. M. (2016). Challenges and prospects of real estate investment trusts (REITs) financing of real estate in Kenya. (A Master of Business Administration Project). University of Nairobi

[20] Keke, O. V., and Emoh, F. I. (2015). Real Estate Investment Trusts (REITs) and Mortgage Backed Securities (MBS) as emerging trends for financing real estate development in the Nigerian Capital Market. International Journal of Civil Engineering Construction and Estate Management, vol. 3(2), pp. 1-7.

[21] McNamara, P. (1998, November) Exploring liquidity: Recent survey findings. Paper to the $7^{\text {th }}$ Investment Property Databank Conference, Brighton.

[22] National, K., Wee, S., \& Ebrahim, S. (2002). Real estate portfolio diversification by sources of return. Journal of Real Estate Portfolio Management, vol 8(1), pp. 1-15. https://doi.org/10.1080/10835547.2002.12089655

[23] NBS (2015). Nigerian real estate sector summary report: 2010-2012. Abuja: National Bureau of Statistics

[24] Newell, G., Pham, A. K., \& Ooi, J. (2015). The significance and performance of Singapore REITs in a mixed-asset portfolio. Journal of Property Investment and Finance, vol. 33(1), pp. 45-65. http://doi.org/10.1108/JPIF-12-2010-0027

[25] Newell, G., \& Marzuki, M. J. B. (2016). The significance and performance of UK-REITs in a mixed-asset portfolio. Journal of European Real Estate Research, vol. 9(2), pp. 171-182. http://doi.org/10.1108/JERER-08-2015-0032

[26] Newell, G., \& Marzuki, M. J. B. (2018). The emergence and performance of German REITs. Journal of Property Investment and Finance, vol. 36(1), pp. 91-103. https://doi.org/10.1108/JPIF-01-2017-0001

[27] Ntuli, M., \& Akinsomi, O. K. (2017). An overview of the initial performance of the South Africa REIT market. Journal of Real Estate Literature, vol. 25 (2), pp. 365-388. https://doi.org/10.1080/10835547.2017.12090463

[28] Odubola, I. (June, 2019). Why investors close eyes on REITs despite prospects, low hanging fruits. Business Day. Retrieved from: https://businessday.ng/real-estate/article/why-investors-close-eyes-on-reits-despite-prospects-low-hanging-fruits/

[29] Odunsi, A. B. (2011). Challenges and performance of adopting REIT structure in financing real estate in Nigeria. (An MSc thesis). Department of Real Estate and Planning, University of Reading, United Kingdom.

[30] Ogedengbe, P. S. and Adesopo, A. A. (2003). Problems of financing real estate in Nigeria. Journal of Human Ecology, vol. 14(6), pp. 425-431. https://doi.org/10.1080/09709274.2003.11905648 


\section{DOI: $\underline{10.51386 / 25815946 / i j s m s-v 4 i 5 p 118}$}

Volume: 4 Issue: 5

September to October 2021

https://www.ijsmsjournal.org

[31] Olanrele, O. O. (2016). Analysis of the performance and acceptance of real estate investment trusts (REITs) in Nigeria. (A PhD thesis). Faculty of the Built Environment, University of Malaya, Kuala Lumpur

[32] Olanrele, O. O., Said, R. \& Daud, M. N. (2015). Comparison of REIT dividend performance in Nigeria and Malaysia. African Journal of Business Management, vol. 9(16), pp. 608-614.

[33] Olanrele, O. O., Said, R., \& Daud, M. N. (2014). REIT performance and option of financing real estate project in developing countries - A case of M-REIT and N-REIT. MATEC Web Conferences 15, 2014.

[34] Olanrele, O. O., Said, R., Daud, M. N., \& Ab Majid, R. A. (2015a). N-REIT performance in the face of index computation and risk adjusted return. A paper presented at the $21^{\text {st }}$ Annual Pacific-Rim Real Estate Society Conference, Kuala Lumpur, Malaysia, 18 - 21 January, 2015.

[35] Olanrele, O. O., Said, R., Daud, M. N., \& Ab Majid, R. A. (2019). REIT financing of real estate development projects in Nigeria: Why not? Journal of Design and Built Environment, vol. 1, pp. 102-115.

[36] Pierdzioch, C., Risse, M., Gupta, R., \& Nyakabawo, W. (2019). On REIT return and (un-)expected inflation: Empirical evidence based on Bayesian additive regression trees. Finance Research Letters, vol. 30, pp. 160-169. http://doi.org/10.1016/j.frl.2018.09.010

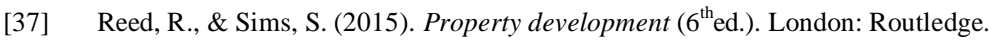

[38] Rozman, A. T., Azmi, N. A., Mohd, H. A., \& Razali, M. N. M. (2015). The performance and significance of Islamic REITs in a mixed-asset portfolio. Jurnal Teknologi, vol. 77:26, 1-9.

[39] Śmietana K., 2014, Diversification principles of real estate portfolio. Real Estate Management and Valuation, vol. 22(1), pp. 54-60. http://doi.org/10.2478/remav-2014-0007

[40] World Bank (2016). Nigeria: Developing housing finance. Washington DC: International Bank for Reconstruction and Development/The World Bank. Retrieved from http://documents.worldbank.org/curated/en/102491481528326920/pdf/110897-WPP131973-PUBLIC-HousingFinanceNigeriaweb.pdf

[41] Xu, Y., \& Yiu, C. Y. (2017). The impacts of tax reforms on REITs. An international empirical study. Academic Journal of Economic, Vol. $\quad 3(1), \quad$ pp. 11-22. https://www.researchgate.net/profile/Yishuang_Xu2/publication/313405528_The_Impacts_of_Tax_Reforms_on_REITs_An_Intern ational_Empirical_Study/links/5899b06b4585158bf6f856bc/The-Impacts-of-Tax-Reforms-on-REITs-An-International-EmpiricalStudy.pdf 